\title{
PUBLIC RESPONSE TO HALAL CERTIFICATION AND LABELLING OF PALEMBANG SPECIAL FOOD TOWARDS PALEMBANG DARUSSALAM VISION
}

\author{
Irham Falahudin $^{1}$, Delia Yusfarani ${ }^{2}$, Ike Apriani ${ }^{3}$ \\ ${ }^{1,2,3}$ Departemen of Biology, UIN Raden Fatah Palembang \\ Correspondence Author: irhamfalahudin_uin@radenfatah.ac.id
}

\begin{abstract}
Palembang City has many variants of typical or traditional food. Palembang specialties such as pempek, laksan, burgo, tekwan are ingredients of local processed products. However, at this time food processing is very complex, manyof the manufacturers in food processing use technology, additives such as dyes or other substances. This composition makes it important for consumers to know about its halalness. This knowledge is important to know how the public responds to whether a product is halal or not. Currently, there are still many typical foods of Palembang City that do not have halal certification and labeling by LPPOM MUI. This study aims to determine the public's response to halal certification and labeling on Palembang typical food products, towards the vision of the city of Palembang Darussalam in realizing halal culinary tourism. The study, which was conducted from MaySeptember 2020, used quantitative methods by collecting data using a questionnaire with 105 respondents. Then to see typical Palembangfoods that are halal and Thayyib, a qualitative food test was carried out. The results of the research on the qualitative test of food were negative for borax and there were five samples containing formaldehyde. The public's response to knowledge of halal certification and labeling on Palembang specialties is directly proportionalto the vision of the city of Palembang.
\end{abstract}

Keyword: Halal Food Community Response, Typical Food, Halal Certificate And Labelling, Vision Of Palembang City.

\section{INTRODUCTION}

Indonesia is one of the largest Muslim countries in the world with a population of approximately $237,641,326$ people based on reports on religious life in 2013 . The number of Muslim population reached $87.21 \%$ or around $207,176,162$ people. The cityof Palembang has a population of 16.023099 people or $4462.99 / \mathrm{km} 2$ with a population growth rate of $1.41 /$ year (BPS, 2017). Indonesian population data is a potential market for halal products. As the largest Muslim country, most of its food products are imported from several non-Muslim countries. Therefore there are some Muslims who are worried about the certification process and halal labelling of products.in circulation. This is because they don't know the process. The understanding that develops in the community, if there is already a halal label on the packaging, then thefood is halal for consumption without knowing the process.

Halal and thayyib foods need to be maintained starting from the process to food safety. Therefore, there is a tendency for people to buy or consume halal and thayyib food products. Several studies on halal product assurance in food such as Maghfiroh (2015) which

Public Response To Halal Certification And Labelling Of Palembang Special Food Towards Palembang Darussalam Vision 
examines the factors that influence the intention to buy packaged food labelledhalal LPPOM MUI. The result is that attitude variables influence the public to buypackaged food that is labelled halal.

Mahmud's research (2017) reports the results of his research on eating from the point of view of the study of halal, haram and syubhathadith, that it is true food that needs to be seen from the halal process. In addition, Adiwibowo's research (2016) explains that food security is important to maintain thestability of the country in protecting people from healthy and safe food for consumption for the Indonesian people. From these three studies, it can be seen how important safe and good food is, in other words, halal food products have a good impact on society.

Palembang specialties such as pempek, laksan, burgo, tekwan are ingredients of local processed products. In the past, the community in food processing was still simple and communication between consumers and producers could still be carried out directly. However, at this time food processing is very complex, many of the producers in food processing use technology to carry out production, additives to dyes or other substances. These uses are very difficult to separate. In addition, communication between producers and consumers has not been well developed. Another problem isthat many producers take the maximum profit from sales, the tight competition makes it possible to make processed food bad.

In addition, the misuse of hazardous chemicals as additives for food and beverage products that are not in accordance with their intended purposes has made many people nervous. Manufacturers use chemicals such as dyes and food preservatives orfood ingredients to make their processed products more attractive, more durable. So that it is more economical and is expected to produce the maximum profit. However, the health impacts arising from the use of these hazardous materials are very bad for the people who consume them. Acute food poisoning and the impact of accumulated carcinogenic chemicals are some of the health problems that consumers will face (Aghnan, 2016).

In realizing and providing solutions for a sense of security for the community in terms of food, tourism, financial products, an agency or institution is needed that guarantees all its products are guaranteed halal. Hasan's research report (2014), certification and fatwas of ulama are important to guarantee a product. In another study, Sikana (2016). Explained that in the qualitative test of food, around $66.7 \%$ of the tofu samples analyzed and circulated in several markets in Palu City were identified to contain formaldehyde so it is not safe for consumption in the long term.

To provide a sense of security, the guarantee of halal products for consumers is important. This changes people's attitudes and mindsets (Peter and Olson, 199) in choosing halal food. Therefore, certification and halal from MUI is required for food products. Halal certificate protects consumers from various inappropriate foods that comply with Islamic syar'iat, especially Muslim-majority Indonesia. This halal certificate encourages competition and becomes superior in food products. The government responded to this effort with Law number 33 of 2014 concerning the organizing agencyfor halal product assurance. The problem 
at this time is that halal certification is not a guarantee of the sustainability of a product's sense of security, therefore a big question arises whether the halal certification and labeling has guaranteed protection and legalcertainty for a halal product for consumers of the Indonesian Muslim community in general and Palembang city in particular.

The importance of halal and thayyib food is a measure of one's religious character. This research will be the basis for public confidence in the assurance of halal certification and labeling on Palembang specialties to achieve the vision of the city of Palembang Darussalam. There is a role from the government as a stake holder who can help in solving problems in the community related to halal certification and labelingof food products.

The description of the background and some of the research that has been carried out have several problems, including whether the public believes in the halal label on every food product packaging. Does the typical food produced by local producers provide a sense of security for food security. What efforts are being made by the government and society to create a good response to halal certification and labeling. Therefore it is important to carry out research on the public's response to halal certification and labeling on Palembang specialties in an effort to realize the vision of the city of Palembang Darussalam.

\section{METHOD}

The research was conducted for three months, namely March to September 2020 in Palembang City and the Biology Laboratory of the Faculty of Science and Technology, Raden Fatah State Islamic University, Palembang. The tools used in this research include scissors, ohause balance, mortar, electric stove, test tube, cup, measuring cup, test tube rack, tweezers, spatula, beaker, digital camera, $\mathrm{pH}$ meter, blender (homogonizer), frezer , questionnaire , test kits of food, turmeric test paper, labels, stationery . Materials that have been used in this research are pempek from 14 Sample in Palembang City, $50 \mathrm{ml} \mathrm{HCl}$, turmeric test paper, distilled water, Reagent A and B formalin test.

The research uses quantitative methods, data collection using a questionnaire with a Likert scale and a qualitative food test. Population and Samples is a 105 respondents. The technique of taking is probability sampling by means of purposive random sampling. To support the data on the public response to the certification and labeling of halal food typicalof Palembang city, it was carried out by qualitative borax and formalin tests. The work steps in this study are as follows:

a) The sampling procedure

1. The sample of typical Palembang food being tested is pempek. Samples were taken by purposive sampling of 14 pempek producers taken from pempek producers in the cityof Palembang. From each producer, three pempek were taken randomly with a total sample of 52 pempek samples.

2. 3 pieces of pempek samples were put into a clear plastic bag and then taken to the FST Biochemistry Laboratory of UIN Raden Fatah Palembang.

3. After that, two qualitative food test procedures were carried out, namely the formalin test 
and the borax test.

b) Borax Test Procedure

1) Pempek samples are cut into small pieces using a knife.

2) Then weigh 5 grams after that crushed using lumpang until smooth.

3) After that, add $10 \mathrm{ml}$ of boiling distilled water, then stir it so that it is homogeneous untilsmooth using a mortar and left for up to 24 hours .

4) Then sample is cooled coupled with $\mathrm{HCl}$ (technical) 4 drops and then stir to homogeneous.

5) Then filtered and taken the filtrate to be identified by qualitative analysis methods.

6) Then take the turmeric test paper, then put it in the test tube until partially submerged.

7) The dipped paper was dried in the sun / dried using room light for 30 minutes.

8) After drying the paper, the dipped part is observed. If the dyed paper forms a brick redcolor, then the sample is indicated positively containing borax $\mathrm{s}$.

c) Formalin content test procedure

1) Pempek samples are cut into small pieces using a knife.

2) Then weigh 5 grams, then crushed using a mortar until smooth.

3) After that, add $20 \mathrm{ml}$ of boiling distilled water, then stir until smooth so that it ishomogeneous using a mortar and left for up to 24 hours.

4) Then filtered and taken the filtrate as much as $5 \mathrm{ml}$ is put into a test tube.

5) Add 4 drops of reagent $A$ and reagent $B$ to the test tube. Then the sample is shaken tomix it homogeneously, then leave it for 10-15 minutes.

6) After that, the colour change in the test tube is observed, if the sample changes the colourof the water to purple, then the food is indicated to be positive for containing formalin.

The data analysis used was instrument analysis by measuring validity and reliability, and hypothesis testing using analysis of variance (ANOVA) with of SPSS v20 software. Testing the reliability of the instrument in this study using the Cronbach Alpha method. The CronbachAlpha method is suitable for use in the scores formed by the Alpha Formula scale:

$$
r_{11}=\left[\frac{k}{(k-1)}\right]\left[1-\frac{\sum \sigma b^{2}}{\sigma^{2} t}\right]
$$

Where:

$\mathrm{r} 11=$ the instrument reliability coefficient sought $\mathrm{k}=$ Number of questions or number of questions

$\sum \mathrm{os}^{2}=$ the total variance in the score of the i-th itemó ${ }^{2} \mathrm{t}=$ total variance 
Cronbach's Alpha Value Range if:

Alpha $<0.50$ low reliability

$0.50<$ alpha $<0.70$ reliability is moderate

Alpha $>0.70$ then the reliability is sufficient (sufficient reliability)Alpha> 0.80 then the reliability is strong

Alpha $>0.90$, the reliability is perfect

\section{RESULT AND DISCUSSION}

The results of the questionnaire that has been given to the people in this study get response good. Public knowledge about halal certification and labelling on a product such as a typical food product in the city of Palembang is good. Of the 105 respondents, the results of the validity and reliability test of the questionnaire items carried out with the SPSS.20 software analysis obtained the following results:

Table 1 Summary of the Test Questionnaire Item Process

\begin{tabular}{|l|l|c|c|}
\hline \multicolumn{2}{|l|}{} & $\mathrm{N}$ & $\%$ \\
\hline \multirow{3}{*}{ Cases } & Valid $^{2}$ & 101 & 96.2 \\
\cline { 2 - 4 } & Excluded $^{\text {a }}$ & 4 & 3.8 \\
\cline { 2 - 4 } & Total $^{2}$ & 105 & 100.0 \\
\hline
\end{tabular}

a. Listwise deletion based on all variables in the procedure.

Table 2 Results of Reliability Statistics Test with the Cronbach Test

\begin{tabular}{|r|l|l|}
\hline Cronbach's Alpha & $\begin{array}{l}\text { Cronbach's Alpha Basedon } \\
\text { Standardized Items }\end{array}$ & \\
\hline .940 & .941 & \\
\hline
\end{tabular}

The results of the validity and reliability of the instrument from the questionnaire answers from all data provided by the community are reliable with a validity rate of $96.2 \%$ (Table 4.1). The greater the percentage level, the more reliable the items used. This is also explained by (Hadi Sutrisno, 2000) that an instrument has constructive validity, if the instrument can be used to measure symptoms that are in accordance with what is defined, in this case the context is measuring the community's response to halal certification and labeling typical of Palembang to the city vision. Palembang. In addition, Borg and Gall (2003) also explain that content validity is the degree of validity that shows that the sample of the items used for measurement or tests represents what is planned to be measured.

Likewise, the reliability level of the resulting items was $94.1 \%$ (Table 4.2). The public's understanding of halal certification and labelling on typical Palembang food varies 
considerably. Each item has a close significance relationship and has an effect on the other item variables, this is shown in Table 4.6. (Single data 0.329 and mean 0.940). The results of the Cronbach test show that the items given by the respondents were $94 \%$. The results of this test indicate that the instruments used to obtain information can be trusted to reveal information in the field as a data collection tool. A questionnaire is said to be reliable or reliable if a person's answer to a statement is consistent over time. Based on the criteria for the Cronbach alpha value $>0.90$, the reliability is perfect (Table 4.2)

The results obtained in this study relate to the public's response to certification and halal labeling on traditional food products to support the vision of the city of Palembang Darussalam. It is divided into four main variables, which are given with 32 question items from all variable items such as table 4-7. the following:

Tables 3 . Quality Of Traditional Food Products

\begin{tabular}{|l|l|c|c|}
\hline No. & \multicolumn{1}{|c|}{$\begin{array}{c}\text { Variable Quality of Food } \\
\text { Products }\end{array}$} & Item Number & $\begin{array}{c}\text { Response Rate } \\
(\%)\end{array}$ \\
\hline 1 & Product information & 1,2 & $\mathbf{7 9 . 5 5}$ \\
\hline 2 & Price & 3,4 & $\mathbf{4 4 . 3}$ \\
\hline 3 & Health & 5,6 & $\mathbf{9 1 . 7 5}$ \\
\hline 4 & Sense of secure & 7,8 & $\mathbf{8 9 . 9 5}$ \\
\hline 5 & Making process & 9,10 & $\mathbf{8 3 . 3 5}$ \\
\hline
\end{tabular}

Questioner results are distributed using the google form online application . The first questionnaire the expected results are that people will know the quality of the traditional pempek food product. From the answers that were entered and provided by the online community, it was obtained a description of the respondents who filled out the questionnaire both on their educational level and work background. Of the 105 respondents, $43.3 \%$ of respondents who answered the questions posed were with a bachelor's level education. There are $36.5 \%$ educated SMA / MA / SMK equivalent and $15.4 \%$ level of master education.

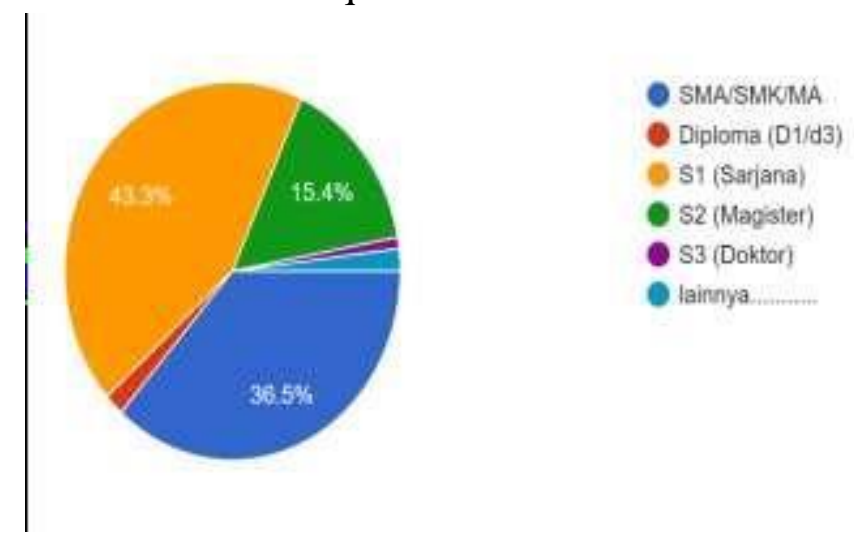

Figure 1 . The level of education of the people who responded to the questionnaire 
In Figure 1, it can be seen that the level of education of the community as respondentsis around $58.7 \%$ with high education, namely undergraduate and master degrees, this shows that the expected understanding of the answers given is truly understood by the community in responding to traditional halal food in Palembang city.

\section{Jenis Kelamin: tos reaponese}
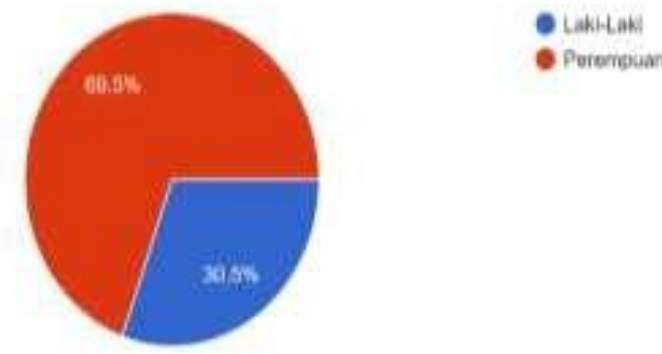

Figure 4 - 2 . Percentage of gender of respondents who participated

To see the positive response opinion from the answers given by the community, there were six questionnaire items made regarding the certification process and halal labeling. There are three groupings regarding halal label as shown in Table 4.8. the following:

Tables 4 . Public understanding of the halal label on Palembang specialties

\begin{tabular}{|c|l|c|c|}
\hline No. & Halal Label Variable & Item Items & Response Rate (\%) \\
\hline 1 & Halal label assessment & 11,12 & $\mathbf{7 2 . 9 ~ 0}$ \\
\hline 2 & $\begin{array}{l}\text { Legalization of halal } \\
\text { label (certification) }\end{array}$ & 13.14 & $\mathbf{7 6 . 3 5}$ \\
\hline 3 & $\begin{array}{l}\text { Halal product } \\
\text { information }\end{array}$ & 15.16 & $\mathbf{6 9 . 7 ~ 0}$ \\
\hline
\end{tabular}

The results are in Table 4. Shows that the average response to legalization of the halal label is good (76.35\%) who responds to answers to the questionnaire. Stanton (2004) states that a label is part of a product that carries verbal information about the product or about the seller. A label can be part of the packaging or also the tag (identification) that is printed on the product. Labels are divided into three classifications, namely: Brand label, Descriptive label, Grade label. In line with this statement, Sukesti and Mamdukh (2014) explain that halal labelling is the inclusion of writing or halal statements on the product packaging to show that the product in question is a halal product. Likewise with the opinion of (Latiff, Z.A.A., Rezai, G., Mohamed, Z. dan Ayob, 2015) that the halal food label consists of three (3) parts, namely:

a. There is a halal logo,

b. There is a composition label

c. There is a nutritional content label 
2. There are a lot of halal food products typical of Palembang city, and around $55 \%$ of data from UKMK, especially pempek sellers, have done halal certification at LPOM MUI South Sumatra. For the decision to buy or consume the food, the researcher asked the community to respond to their decision to buy the product. This is done to see the knowledge of the peopleof Palembang on the importance of traditional food, in this case pempek food which has a halal certification and logo.

Tables 5 . Public Response In Consuming Traditional Halal Food Products

\begin{tabular}{|c|l|c|c|}
\hline No. & $\begin{array}{c}\text { Variable Decision to Buy /Use } \\
\text { Products }\end{array}$ & Item Items & nse Rate(\%) \\
\hline 1 & Public interest & 17.18 & $\mathbf{6 5 . 3 5}$ \\
\hline 2 & Like / match & 19,20 & $\mathbf{7 2 . 6 0}$ \\
\hline 3 & The need & 21,22 & $\mathbf{7 2 . 1 ~ 0}$ \\
\hline
\end{tabular}

To support the results of the questionnaire, a qualitative test was carried out by conducting a formalin test, the results were as follows:

Tables 6 . Formalin Test Results On Typical Palembang Foods

\begin{tabular}{|c|c|c|c|c|c|c|}
\hline \multirow{2}{*}{ Sample Code } & \multicolumn{4}{|c|}{ Formalin Test } & \multicolumn{3}{c|}{ Borax Test } \\
\cline { 2 - 8 } & $\mathbf{1}$ & $\mathbf{2}$ & $\mathbf{3}$ & $\mathbf{1}$ & $\mathbf{2}$ & $\mathbf{3}$ \\
\hline 1 & - & + & - & - & - & - \\
\hline 2 & + & + & + & - & - & - \\
\hline 3 & + & + & + & - & - & - \\
\hline 4 & - & - & - & - & - & - \\
\hline 5 & + & - & - & - & - & - \\
\hline 6 & - & - & - & - & - & - \\
\hline 7 & + & - & + & - & - & - \\
\hline 8 & - & - & - & - & - & - \\
\hline 9 & - & - & - & - & - & - \\
\hline 10 & - & - & - & - & - & - \\
\hline 11 & - & - & - & - & - & - \\
\hline 12 & - & - & - & - & - & - \\
\hline 13 & - & - & - & - & - & - \\
\hline 14 & - & - & - & - & - & - \\
\hline
\end{tabular}

Information: (-) negative formalin/Borax and (+) positive formaldehyde/borax (Source: primary data, 2020) 
Public knowledge and awareness of halal products make the growth of the halal industry increase (Nasaruddin et al., 2012); (D Hamdan, M Z El-Readi, E Nibret, F Sporer, N Farrag, A El-Shazly, 2010). The increase in the halal industry has led to halal tourism ( halal tourism ) as a new phenomenon (Samori et al., 2016). This is also supported by various literatures that explain that Muslim tourists care about the consumption of products and services according to sharia when visiting tourist attractions ((Battour et al., 2011); (Jafari \& Scott, 2013).

The relation of typical halal food products in Palembang, Palembang people and the general public to buy these food products see the halal certification and label. This has become very strategic for the city of Palembang, as an effort to develop halal tourism. Indonesia is trying to increase the existence of Islamic hotels and restaurants as well as Islamic culinary. The government through the Regulation of the Minister of Tourism and Creative Economy of Indonesia has made guidelines for the operation of Islamic hotels. Sharia referred to here is the principles of Islamic law as regulated by fatwas and / or has been approved by the Indonesian Ulema Council (MUI). In 2013, there are 37 sharia hotels that have been certified halal and 150 hotels are heading for sharia operations. There are 2,916 restaurants and 303 of them have been certified halal, and 1,800 are preparing for certification (Pariwisata, 2018).

In general, food and beverages in Indonesia are certified halal by the MUI which is marked with the official halal logo on food and beverage packaging, and is inspected by the Food and Drug Supervisory Agency (BPOM). With supervision from BPOM, food and drinks available in Indonesia are guaranteed to be halal for Muslim tourists. Meanwhile, non-Muslim tourists can be sure that these foods and drinks do not contain harmful substances for the body, so they are suitable for consumption (Jaelani, 2017).

Tables 8. ANOVA ${ }^{a}$

\begin{tabular}{|l|r|r|r|r|l|}
\hline Model & \multicolumn{1}{l|}{ Sum of } & df & Mean Square & F & Sig. \\
& Squares & & & & \\
\hline Regression & 131,304 & 1 & 131,304 & 34,221 & $.000^{\mathrm{b}}$ \\
1 & 395,210 & 103 & 3,837 & & \\
Residual & 526,514 & 104 & & & \\
\hline
\end{tabular}

a. Dependent Variable: X1

b. Predictors: (Constant), Y1

The results of the analysis from the summary of the model carried out can be concluded that there is a close relationship between the quality of traditional food products, in this case pempek produced by producers in the city of Palembang (X1) with a strong response. 


\section{CONCLUSION}

From the results of the discussion that has been done it can be concluded that:

1. The public response to certification labeling and halal labeling on Palembang typical food products is very good, and this knowledge has a significant effect on the consumption or use of typical Palembang food. The results obtained are $\mathrm{F}$ count (99.958)> F table $\alpha$ 5\% (0.195)

2. The government's efforts in realizing the vision of the city of Palembang to the public's response to the certification and labeling of halal food typical of the city of Palembang arestill low where F count (28.570)> F table $\alpha 5 \%$ (0.195). Therefore there needs to be an effort from the city government of Palembang to make regulations on halal food products to support Palembang as one of the halal culinary tourism destinations.

\section{ACKNOWLEDGMENTS}

Researchers express their deepest gratitude to Prof. Dr. Nyayu Khadijah, M.Si. Rector of UIN Raden Fatah Palembang; Prof. Dr. Paisol Burlian, M.Hum, as the chairman of LP2M who has provided supporting funds for the completion of this research, Dr. Achmad Syarifuddin, M.A. as a reviewer; Dr. Syaiful Eddy, M.Si. as a resource person in the seminar results. Dr. Validator Team Azhar, M.Si., Dr. Jasmi, M.Si and Dr. Endang Rochmiatun, M.Hum.for all the suggestions and input. The Head of the FST Biochemistry Laboratory who has granted permission for qualitative testing of food in the laboratory and the data analysis team as well as the Biology study program lecturer, all contributed to the success of this research. May Allah reward all his good deeds.

\section{REFERENCES}

Adiwibowo, Y. (2016). Epistemologi Ideologi Keamanan Pangan. Yuridika, 31(1), 119. https://doi.org/10.20473/ydk.v31i1.1962.

Aghnan. (2016). No Title. Bahan Pengawet Dan Penyedap Dalam Makanan (Boraks, Formalin, dan MSG).

Badan Pusat Statistik. (2018). Statistik Lingkungan Hidup Indonesia (SLHI) 2018. Badan Pusat Statistik/BPS-Statistics Indonesia, 1-43. https://doi.org/3305001.

Battour, M., Ismail, M. N., \& Battor, M. (2011). The impact of destination attributes on Muslim tourist's choice. International Journal of Tourism Research, 13(6), 527-540. https://doi.org/10.1002/jtr.824

D Hamdan, M Z El-Readi, E Nibret, F Sporer, N Farrag, A El-Shazly, M. W. (2010). Chemical composition of the essential oils of two Citrus species and their biologicalactivities. 
Pharmazie, 65((2)), 141-147. https://pubmed.ncbi.nlm.nih.gov/20225661/

Hadi Sutrisno. (2000). Metodologi research: untuk penulisan paper skripsi, thesis dan disertasi.

Andi.Hasan, K. S. (2014). Kepastian Hukum Sertifikasi Dan Labelisasi Halal Produk Pangan.

Jurnal Dinamika Hukum, 14(2), 227-238. https://doi.org/10.20884/1.jdh.2014.14.2.292 Jaelani, A. (2017). Halal Tourism Industry in Indonesia: Potential and Prospects. SSRN Electronic Journal, July. https://doi.org/10.2139/ssrn.2899864

Jafari, J., \& Scott, N. (2013). Muslim world and its tourisms. Annals of Tourism Research,44. https://doi.org/10.1016/j.annals.2013.08.011

Latiff, Z.A.A., Rezai, G., Mohamed, Z. dan Ayob, M. A. (2015). Food Labels' Impact Assessment on Consumer Purchasing Behavior in Malaysia. Journal of Food Products Marketing, 22(2), 1-14.

https://www.tandfonline.com/doi/full/10.1080/10454446.2013.856053.

Maghfiroh, M. (2015). Faktor-Faktor Yang Memengaruhi Niat Membeli Makanan Kemasan $\begin{array}{lllll}\text { Berlabel Halal Lppom-Mui. Jurnal } & \text { Economia, }\end{array}$ https://doi.org/10.21831/economia.v11i2.8240.

Mahmud, A. (2017). Kajian Hadis tentang Halal, Haram, dan Syubhat. Jurnal Adabiyah, 17(2), 124-142. https://doi.org/10.24252/jad.v17i1i2a3.

Nasaruddin, R. R., Fuad, F., Mel, M., Jaswir, I., \& Hamid, H. A. (2012). The importance of a standardized Islamic Manufacturing Practice (IMP) for food and pharmaceutical productions. Advances in Natural and Applied Sciences, 6(5 SPL.ISS. 4), 588-595.

https://doi.org/10.13140/2.1.3112.3520.

Pariwisata, K. (2018). Laporan Akuntabilitas Kinerja Kemetrian Pariwisata 2018. Psychology Applied to Work: An Introduction to Industrial and Organizational Psychology, Tenth Edition Paul, 53(9), 1689-1699.

Peter J. Paul dan C. Olson.L. (1999). No Title (S. Yati (ed.); 4th ed.). Erlangga.

Samori, Z., Md Salleh, N. Z., \& Khalid, M. M. (2016). Current trends on Halal tourism: Cases on selected Asian countries. Tourism Management Perspectives, 19(June 2020), 131- 136. https://doi.org/10.1016/j.tmp.2015.12.011.

Sikanna, R. (2016). Analisis Kualitatif Kandungan Formalin Pada Tahu Yang Dijual Dibeberapa Pasar Di Kota Palu. Kovalen, 2(2), 85-90. https://doi.org/10.22487/j24775398.2016.v2.i2.6729 